CZASOPISMO INŻYNIERII LA¿DOWEJ, ŚRODOWISKA I ARCHITEKTURY JOURNAL OF CIVIL ENGINEERING, ENVIRONMENT AND ARCHITECTURE JCEEA, t. XXX, z. 60 (1/13), styczeń-marzec 2013, s. 59-65

\author{
Natalia MIRONOVA ${ }^{1}$ \\ Galina KALDA ${ }^{2}$ \\ Oleg LISHCHUK ${ }^{3}$
}

\title{
HYDROCHEMICAL AND TOXICOLOGICAL COMPOSITION IN TECHNOGENIC LAKES OF MALE POLISSYA IN UKRAINE
}

\begin{abstract}
The article presents the research results of hydrochemical indicators and assessment phytotoxic conditions (heavy metals content) in inactive water-filled sandpit (technogenic lakes) in the area of Male Polissya of Ukraine. Determined that these new man-made elements hydrographic network of have allowable values hydrochemical parameters and heavy metals in water and pit-bottom sediments, therefore suitable for recreational use. Extraction of mineral resources by opencast methods involve violations of lithogenic base of the landscape, changing the hydrological regime, and thus the destroying of natural ecosystems. The physicalgeographical area of Male Polissya is located between Volhynia forest-steppe sublimity in the north, Roztochchyam north-west and by Podil'skoy forest-steppe sublimity on a southeast. Stretched out from Zhytomyr part of Ukrainian Polissya on east to Rava-Ruska on a west and farther passes to territory of Poland. A special feature of the sand extraction in the eastern part of Male Polissya is development of water-filled pits, which initially had the sand extraction from the surface layer, and then, when the pit depth reached groundwaters level and the pit got gradually filled with them - from the water layers with the help of dredges. The objects of the research are man-made water body that were formed in the eastern part of the Male Polissya from the late 60 -ies of the $20^{\text {th }}$ century during active development of the area as a resource base for sand extraction for the needs of the construction industry. At present, most of the water-filled sand pits are not being developed and essentially they are man-made lakes. They differ from natural lakes by the structure of the bottom and littoral zone, as in the formation of them the leading role was played by not natural, but technological and economic factors of pit
\end{abstract}

\footnotetext{
${ }^{1}$ Autor do korespondencji: Natalia Mironova, National Forestry University of Ukraine, Khmelnytsky National University, 11 Instytutska Street, Khmelnytsky, 29016 Ukraine, +380671177093, miron@tup.km.ua.

${ }^{2}$ Galina Kalda, National Forestry University of Ukraine, Khmelnytsky National University, 11 Instytutska Street, Khmelnytsky, 29016 Ukraine, +38 0974785986, kalda@ tup.km.ua.

${ }^{3}$ Oleg Lishchuk, National Forestry University of Ukraine, Khmelnytsky National University, 5 Naukowa Street, Lviv, 38012 Ukraine, +38 0678023871, olishczuk@ 1ltu.lv.ua.
} 
development. The considerable depth of these lakes $(5-25 \mathrm{~m})$ and low levels of suspended solids in the water makes it blue color, so that local people often call cascades of these reservoirs "Blue Lakes".

Keywords: technogenic lakes, sand pits, hydrochemical composition, heavy metals

\section{Introduction}

Extraction of mineral resources by opencast methods involve violations of lithogenic base of the landscape, changing the hydrological regime, and thus the destroying of natural ecosystems.

Choice in remediation directions of the used pit fields depends on the technological features of mining activities. Today the water remediation of pit becomes a very important, and the result of this is the creation of reservoirs to replace the sand pits. An example of this approach is the recultivation of quarry in Germany [1], Poland [2], sulfur pits in Lviv region [1, 3]. Further tasks of converting these reservoirs into recreational objects are the study and monitoring of hydrochemical parameters that will serve as the basis for development of biological reclamation.

The physical-geographical area of Male Polissya is located between Volhynia forest-steppe sublimity in the north, Roztochchyam north-west and by Podil'skoy forest-steppe sublimity on a southeast. Stretched out from Zhytomyr part of Ukrainian Polissya on east to Rava-Ruska on a west and farther passes to territory of Poland.

A special feature of the sand extraction in the eastern part of Male Polissya is development of water-filled pits, which initially had the sand extraction from the surface layer, and then, when the pit depth reached groundwaters level and the pit got gradually filled with them - from the water layers with the help of dredges.

At the end of operation terms, such pits represent artificial reservoirs of technogenic origins (man-made lakes) with a specific and unique combination of environmental factors. This eliminates the need for flooding to be carried out as the first phase of water reclamation, and displays the priorities to determine hydrochemical and toxicological conditions for the created reservoirs with further development of reclamation measures to optimize water environment and formation real reservoir, which can be used for the purposes of recreation and environmental protection.

\section{Materials and methods of research}

The objects of the research are man-made water body that were formed in the eastern part of the Male Polissya from the late 60 of the $20^{\text {th }}$ century during active development of the area as a resource base for sand extraction for the needs of the construction industry. 
At present, most of the water-filled sand pits are not being developed and essentially they are man-made lakes. They differ from natural lakes by the structure of the bottom and littoral zone, as in the formation of them the leading role was played by not natural, but technological and economic factors of pit development. The considerable depth of these lakes (5-25 m) and low levels of suspended solids in the water makes it blue color, so that local people often call cascades of these reservoirs „Blue Lakes”.

In order to determine the hydrochemical and toxicologic conditions manmade lakes and development of directions for further use of these reservoirs, the hydrochemical indicators and concentration of heavy metals in the water and and pit-bottom sediments was studied. When collecting the samples, preparing them for analysis, and evaluation of results, the current Ukrainian regulatory and methodical documents were used. Determination of heavy metals were carried out by atomic absorption spectroscopy.

\section{Research results and discussion}

In man-made landscapes where specific conditions are created due to changes in lithogenic base and hydrological regime, one of the leading preliminary stages of the research and basic foundation for the fitomelioration activities are hydrochemical and hydrotoxic conditions of the technogenic reservoir. It is they characterize the suitability of abiogenic factors reservoir for the formation and development of the ecological community.

Technogenic lakes of Male Polissya have a mixed type of power supply (groundwater, snow melt water and precipitation). The biggest influence on the hydrochemical parameters due to the considerable depth of lakes has a chemical composition of groundwater, which is a positive condition because snow water and precipitation today referred to as potential carriers of anthropogenic pollution and they often worsen the hydrochemical composition of waterbodies.

Groundwater of study area formed in the Quaternary sediments and are called hydrocarbon calcium or hydrocarbon sodium-calcium with mineralization of $0,39-0,62 \mathrm{~g} / \mathrm{dm}^{3}$, moderate hardness $3,7-6,7 \mathrm{mg} \cdot \mathrm{ekv} / \mathrm{dm}^{3}$ and weakly alkaline reaction $\mathrm{pH}[4]$.

We set the chemical composition of technogenic lakes of Male Polissya (Table 1), which in general is not significantly different from the chemical composition of groundwater and concentration standards in the field of fisheries and water for industrial, cultural and domestic purposes, approved in Ukraine. So hydrochemical conditions of these lakes are favorable for fitomelioration activities and secure development of biocenosis and recreational use.

An important condition for the security of technogenic lakes is to match their toxicological parameters for standards, especially on the content of heavy metals. From the environmental point of view, the entry of toxic substances into the water of technogenic lakes is considered as a process of toxification. 
Table 1. Average values of hydrochemical parameters of technogenic lakes

Tabela 1. Średnie wartości parametrów hydrochemicznych jezior technogennych

\begin{tabular}{|c|l|c|c|c|c|}
\hline No & Parameter & $\begin{array}{c}\text { Measurement } \\
\text { unit }\end{array}$ & $\begin{array}{c}\text { Standards for } \\
\text { industrial water } \\
\text { and drinking water }\end{array}$ & $\begin{array}{c}\text { Standards } \\
\text { for fishery } \\
\text { water }\end{array}$ & $\begin{array}{c}\text { Average } \\
\text { parameters }\end{array}$ \\
\hline 1 & $\mathrm{pH}$ & instrument & $6,5-8,5$ & - & 7,9 \\
\hline 2 & Color & {$[\mathrm{degree}]$} & $<35$ & - & 9 \\
\hline 3 & Suspended solids & {$\left[\mathrm{mg} / \mathrm{dm}^{3}\right]$} & - & - & 24,1 \\
\hline 4 & Ammonium salt & {$\left[\mathrm{mg} / \mathrm{dm}^{3}\right]$} & 2,6 & 0,5 & 0,2 \\
\hline 5 & Nitrites & {$\left[\mathrm{mg} / \mathrm{dm}^{3}\right]$} & 3,30 & 0,08 & 0,01 \\
\hline 6 & Nitrates & {$\left[\mathrm{mg} / \mathrm{dm}^{3}\right]$} & 45,0 & 40,0 & 0,7 \\
\hline 7 & Soluble oxygen & {$\left[\mathrm{mg} \mathrm{O}_{2} / \mathrm{dm}^{3}\right]$} & $\geq 4,0$ & $\geq 6,0$ & 6,6 \\
\hline 8 & BSK $/$ BSK 20 & {$\left[\mathrm{mg} \mathrm{O} / \mathrm{dm}^{3}\right]$} & $-/ \leq 3,0$ & $-/ \leq 3,0$ & $1,5 / 1,7$ \\
\hline 9 & Alkalinity & {$\left[\mathrm{mg} \cdot \mathrm{ekv}^{3} / \mathrm{dm}^{3}\right]$} & $0,5-6,5$ & - & 2,8 \\
\hline 10 & Stiffness & {$\left[\mathrm{mg} \cdot \mathrm{ekv}^{3} / \mathrm{dm}^{3}\right]$} & 7,0 & - & 2,7 \\
\hline 11 & Dry residue & {$\left[\mathrm{mg} / \mathrm{dm}^{3}\right]$} & 1000 & - & 230 \\
\hline 12 & Chlorides & {$\left[\mathrm{mg} / \mathrm{dm}^{3}\right]$} & 350 & 300 & 4,7 \\
\hline 13 & Sulfates & {$\left[\mathrm{mg} / \mathrm{dm}^{3}\right]$} & 500 & 100 & 44 \\
\hline 14 & Calcium & {$\left[\mathrm{mg} / \mathrm{dm}^{3}\right]$} & 180 & 180 & 63 \\
\hline 15 & Magnesium & {$\left[\mathrm{mg} / \mathrm{dm}^{3}\right]$} & 40 & - & 2,5 \\
\hline 16 & Hydro-carbonates & {$\left[\mathrm{mg} / \mathrm{dm}^{3}\right]$} & - & - & 164,1 \\
\hline 17 & Phosphates & {$\left[\mathrm{mg} / \mathrm{dm}^{3}\right]$} & - & - & 0 \\
\hline 18 & Sulfide ions & {$\left[\mathrm{mg} / \mathrm{dm}^{3}\right]$} & 0 & - & 2,7 \\
\hline 19 & Silikat ions & {$\left[\mathrm{mg} / \mathrm{dm}^{3}\right]$} & 30 & & \\
\hline
\end{tabular}

Marker ,-" means that this option for this reservoir is not standardized.

Among the heavy metals the most important role in water pollution plays zinc, lead, cadmium, copper, nickel etc. Toxicity of some compounds varies greatly and differs for different aquatic organisms. Lead is highly toxic for many macrophytes in concentrations above $0,1 \mathrm{mkg} / \mathrm{dm}^{3}$, cadmium $-1 \mathrm{mg} / \mathrm{dm}^{3}$ [5].

Aquatic organisms can accumulate in their tissues unusually high concentrations of heavy metals. Moreover, the levels of accumulation of metals in their organisms reflect not only the concentration of pollutants in the environment, but also their bioavailability to living organisms, which is based on toxicity. Ecological effects of pollutants appear on the level of organisms, population, biocenotic level and ecosystem levels.

At the level of organisms there may be observed violations of certain physiological functions, behavior change, reduction in the growth rate, the increase in mortality due to direct poisoning or decrease in the resistance to stress state of the environment. At the population level, the pollution can cause changes in the numbers and biomass, fertility and mortality, sex and size structure, dynamics and a number of functional properties [6]. 
In biocenotical levels the pollution appears to change the structure and function of a community as one and the same contaminant affects differently the components of the biological community. Under the influence of toxic substances the chorological structure changes and the chain decomposition begins to dominate, anaerobic processes dominate over aerobic processes, destruction over products. Finally, the degradation of ecosystems take place, they deteriorate as elements of human environment and reduce their positive role in shaping of biosphere, depreciation in economic terms (replacing valuable species by the species of little value, the appearance of harmful species etc.) [5]. For this reason, we determined the content of heavy metals in water of technogenic lakes (Table 2).

Table 2. Average content of heavy metals in technogenic lakes water

Tabela 2. Średnia zawartość metali ciężkich w technogennych wodach jezior

\begin{tabular}{|c|c|c|}
\hline Chemical element & $\begin{array}{c}\text { The content in } \\
\text { water sample } \\
{\left[\mathbf{m g} / \mathbf{d m}^{\mathbf{3}}\right]}\end{array}$ & $\begin{array}{c}\text { Standard for water objects of industrial and } \\
\text { drinking, cultural and common purpose } \\
{\left[\mathbf{m g} / \mathbf{d m}^{\mathbf{3}}\right]}\end{array}$ \\
\hline $\mathrm{Cu}$ & 0,012 & 1,0 \\
\hline $\mathrm{Ni}$ & 0,07 & 0,1 \\
\hline $\mathrm{Zn}$ & 0,06 & 1,0 \\
\hline $\mathrm{Pb}$ & $<0,01$ & 0,03 \\
\hline $\mathrm{Cd}$ & $<0,0001$ & 0,001 \\
\hline $\mathrm{Fe}$ & 0,030 & 0,3 \\
\hline
\end{tabular}

Analysis of the data table indicates the compliance of their concentration to the standards in the field of fisheries and water for industrial, cultural and domestic purposes, approved in Ukraine.

Evaluation of toxic conditions on the content of heavy metals in the water only can not be complete, because the formation of technogenic lakes accompanied by the gradual uncovering of rocks that may have increased the concentration of heavy metals with depth.

At the expense of dynamic processes in the system ,water - bottom sediments" is potentially a transition of toxic substances in the water column, which may influence the toxicity of the water environment for aquatic organisms. In addition, the development rooted higher aquatic plants that perform multiple functions in water (decorative aesthetic, sedimentation, consolidation etc.), on the toxic substrates is limited [7].

We examined content of mobile forms of heavy metals in pit-bottom sediments (Table 3), as they characterize migration ability of elements and their ability to move into other media, and especially - water and in plant biomass.

It must be noted that today in Ukraine there are no approved standards for the content of heavy metals in bottom sediments of natural waters. Therefore, 
the relative assessment of the degree of contamination of bottom sediments can be given on the basis of comparison with clark content in sedimentary rocks. Analysis of Table 3 indicates small content of water-soluble forms of heavy metals in pit-bottom sediments.

Table 3. The content of mobile forms of heavy metals in pit-bottom sediments of technogenic lakes

Tabela 3. Zawartość mobilnych form metali ciężkich w osadach dennych jezior technogennych

\begin{tabular}{|c|c|c|}
\hline Chemical element & $\begin{array}{c}\text { Content in sediments } \\
{[\mathbf{m g} / \mathbf{k g}]}\end{array}$ & $\begin{array}{c}\text { Clark metal } \\
{[\mathbf{m g} / \mathbf{k g}]}\end{array}$ \\
\hline $\mathrm{Cu}$ & 0,17 & 57 \\
\hline $\mathrm{Ni}$ & 0,028 & 95 \\
\hline $\mathrm{Zn}$ & 2,1 & 80 \\
\hline $\mathrm{Pb}$ & $<0,05$ & 20 \\
\hline $\mathrm{Cd}$ & $<0,005$ & 23 \\
\hline
\end{tabular}

\section{Conclusions}

Inactive water-filled sandpit (technogenic lakes) in the area of Male Polissya of Ukraine can serve as a formation element of artificial aquatic landscape suitable for recreational use, because the determined by us hydrochemical parameters and content of heavy metals in water meets the maximum permissible concentration for standards in the field of fisheries and water for industrial, cultural and domestic purposes.

Small amounts of heavy metals in bottom sediments make it possible to conclude about the improbability of re-contamination of water masses by the metals due to their remobilization from bottom sediment.

\section{References}

1. Didukh O.I.: Formation of hydrochemical parameters in artificial lakes (on the example of Javoriv Lake). First Ukrainian Meeting of the Ecologists (ECOLOGY-2006): Abstracts from the International Scientific Conference, O.I. Didukh, M.S. Malyovany (ed.). Vinnytsya October 4-7, 2006, UNIVERSUM-Vinnytsya 2006.

2. Kasztelewicz Z.: Poprawianie krajobrazu. Rekultywacja terenów pogórniczych w polskich kopalniach odkrywkowych. Cz. II. Surowce i Maszyny Budowlane, 1, 2011, 73-74.

3. Kucheryavy V.P.: Reclamation and fitomelioration. Manual. V.P. Kucheryavy, Y.V. Genyk, A.P. Dyda, M.M. Kolodko (ed.). Svit, Lviv 2006.

4. Zylov E.A.: Hydrobiology and water Ecology (organization, functioning and pollution of ecosystems): training manual. Publishing house of Irkutsk State University, Irkutsk 2009.

5. Kucheryavy V.P.: General Ecology. Svit, Lviv 2010.

6. Krot Y.G.: Using of up-water aquatic plants in biotechnology for cleaning of upper waters and sewage waters. Hydrobiological Journal, 42, 1, 2006, 47-61.

7. Sadchikov A.P.: Ecology of coastal-water vegetation (training manual for students of high schools. Publishing house NIA-Priroda, REFIA 2004. 


\section{HYDROCHEMICZNY I TOKSYKOLOGICZNY SKLAD TECHNOGENNYCH JEZIOR NA TERENIE MALEGO POLESIA UKRAIŃSKIEGO}

\section{Streszczenie}

Artykuł prezentuje rezultaty poszukiwań wskaźników hydrochemicznych i oceny warunków fitotoksycznych (zawartości metali ciężkich) w nieczynnej, wypełnionej wodą piaskownicy (jeziorze technogennym) na terenie Polesia Ukraińskiego. Ustalono, że te nowe sztuczne elementy sieci hydrograficznej, mające dopuszczalne wartości parametrów hydrochemicznych i metali ciężkich w wodzie i osadach dennych, nadają się do wykorzystania rekreacyjnego. Wydobycie surowców mineralnych metodami odkrywkowymi wiąże się z litologicznym naruszeniem stanu krajobrazu, zmianą reżimu hydrologicznego, a tym samym ze zniszczeniem naturalnego ekosystemu.

Fizyczno-geograficzny obszar Polesia jest zlokalizowany pomiędzy wołyńskimi leśnostepowymi wyniosłościami na północy Ukrainy, Roztoczem na północnym zachodzie i podolskimi leśno-stepowymi wyniosłościami na południowym wschodzie. Obszar ten jest rozciągnięty od części żytomierskiego Polesia Ukraińskiego do Rawy Ruskiej, a dalej przechodzi na terytorium Polski.

Szczególną cechą wydobycia piasku we wschodniej części Polesia jest rozwój wypełnionych wodą dołów, które były początkowo wydobywane $\mathrm{z}$ warstwy powierzchniowej, a potem - gdy głębokość dołów osiągnęła poziom wód gruntowych i zostały one stopniowo nimi wypełnione z warstwy wodnej za pomocą pogłębiarek.

Obiektami badań były sztuczne zbiorniki wodne, które zostały utworzone we wschodniej części Polesia w latach 60. XX wieku w okresie intensywnego rozwoju obszaru jako bazy surowcowej dla wydobycia piasku na potrzeby budownictwa. Obecnie większość piaskowych dołów wypełnionych wodą to sztuczne jeziora. Różnią się one od naturalnych jezior strukturą dna i strefą brzegowa, a w ich tworzeniu wiodącą rolę odegrały nie naturalne, lecz technologiczne i ekonomiczne czynniki rozwoju dołów. Znaczna głębokość tych jezior $(5-25 \mathrm{~m})$ oraz niski poziom zawiesiny w wodzie sprawiają, że woda przybiera kolor niebieski. Miejscowa ludność kaskady tych zbiorników często nazywa „niebieskimi jeziorami”.

Słowa kluczowe: jeziora technogenne, piaskownica, skład hydrochemiczny, metale ciężkie

DOI: $10.7862 / \mathrm{rb} .2013 .5$

Przesłano do redakcji w styczniu $2013 r$.

Przyjęto do druku w czerwcu 2013 r. 